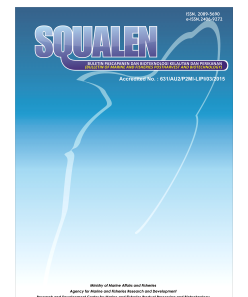

www.bbp4b.litbang.kkp.go.id/squalen-bulletin

Squalen Bulletin of Marine and Fisheries Postharvest and Biotechnology

ISSN: $2089-5690$

e-ISSN: 2406-9272

\title{
Golden Sea Cucumber: Identification and the Antioxidant Activity of Its Collagen Hydrolysates
}

\author{
Yusro Nuri Fawzya, Nugrah Analiadi Putra, Arif Budi Witarto, and Gintung Patantis \\ ${ }^{1}$ Research Center for Marine and Fisheries Product Processing and Biotechnology \\ Jalan K.S. Tubun, Petamburan VI, Jakarta Pusat, Indonesia 10260 \\ ${ }^{2}$ Sumbawa University of Technology \\ Jl. Raya Olat Maras, Moyo Hulu, Kab. Sumbawa, Nusa Tenggara Barat, Indonesia 84371 \\ ${ }^{3}$ Department of Biochemistry and Molecular Biology, Faculty of Medicine, Indonesia Defense University \\ Kawasan IPSC Sentul, Sukahati, Kec. Citeureup, Bogor, Jawa Barat Indonesia 16810 \\ Article history: \\ Received: 16 October 2020; Revised: 30 October 2020; Accepted: 15 November 2020
}

\begin{abstract}
Golden sea cucumber or locally known as "teripang emas" is one of Indonesia's most popular sea cucumber and widely processed as functional food or supplement due to its bioactivities. The sea cucumber is often misidentified due to its morphological similarities with other Stichopus spp. This study aimed to identify the golden sea cucumber obtained from West Nusa Tenggara, Indonesia, by a molecular method and study the antioxidant activities of its collagen hydrolysates. The hydrolysates were produced by hydrolyzing acid collagen extract using neutrase for 30 , $60,120,180$, and 240 mins. The products were then analyzed for their degree of hydrolysis, peptide content, molecular weight distribution and radical scavenging activity by the 2,2-Diphenyl-1-picrylhydrazyl (DPPH) method. Results showed that hydrolysis for 180 mins was optimal in producing the highest peptide content, $12.79 \pm 0.44$ $\mathrm{mg} / \mathrm{mL}$, with a degree of hydrolysis $(\mathrm{DH})$ of $55.2 \pm 1.50 \%$. However, the highest antioxidant activity $\left(\mathrm{IC}_{50}\right.$ of $5.25 \pm 0.15$ $\mathrm{mg} / \mathrm{mL}$ ) was demonstrated after 60 mins hydrolysis with molecular weight (MW) ranged from less than $14.4 \mathrm{kDa}$ to approximately $25 \mathrm{kDa}$. The hydrolysate might be categorized as a weak to moderate antioxidant. Based on the molecular identification, the golden sea cucumber had $99 \%$ similarities with Stichopus horrens and S. monotuberculatus.
\end{abstract}

Keywords: golden sea cucumber, identification, collagen hydrolysates, neutrase, antioxidant

\section{Introduction}

Sea cucumbers have long been known as a potential source of functional food and biomedicine products. This is because their various compounds contain therapeutic activities, such as saponin, chondroitin sulfates, fatty acids, vitamins, minerals, bioactive collagen peptides, amino acids, etc. (Bordbar, Anwar \& Saari, 2011). Various Indonesian sea cucumbers have been explored for their potential bioactivities (Adriansyah \& Sulastri, 2014; Dewi, Patantis, Fawzya, Irianto, \& Sa'diah, 2020; Khirzin, Sukarno, Yuliana, Fawzya, \& Chasanah, 2015; Pangestuti \& Arifin, 2018). However, many other local Indonesian sea cucumbers need further exploration of their biological activities related to their health benefit effects and possibilities as new sources of functional constituents.

Golden sea cucumber belongs to the genus Stichopus, which can be found in Sumatra, Nusa Tenggara and Sulawesi waters (Fad'ha, Arma, \& Busman, 2019; Nursid, Marraskuranto, Kuswardini, \& Winanto, 2019; Pangestuti et al., 2016; Safithri, Setyaningsih, Tarman, Yuhendri, \& Meydia, 2018). To date, golden sea cucumbers are often called Stichopus hermannior S. variegatus because of their similar morphological characteristics. For the same reason, misidentification often occurs to differentiate between $S$. horrens, S. monotuberculatus, $S$. quadrifasciatus and $S$. naso (Purcell, Samyn, \& Conand, 2012). Identification using the mitochondrial

${ }^{*}$ Corresponding author.

E-mail: nurifawzya@gmail.com 
cytochrome c oxidase subunit I (COI) gene could distinguish several species in a specific genus of dried sea cucumber (Patantis, Dewi, Fawzya, \& Nursid, 2019). Based on the previous studies above, molecular identification should be done to confirm the species of golden sea cucumber.

Similar to other sea cucumbers of high economic values, most golden sea cucumbers are processed into beche-de-mer. They also have been widely used for traditional healing products, which are trending now, shown by the number of supplement products on the market. However, the utilization of golden sea cucumbers found in West Nusa Tenggara is still limited to the dried food products.

Research on the biological activity of sea cucumbers from Nusa Tenggara have been reported, including radical scavenging activity of ethanolic extract of Holothuria leucospilota, $\mathrm{H}$. atra, $\mathrm{H}$. fuscocinerea, and $H$. excellens (Pangestuti et al., 2016), $\alpha$-glucosidase inhibition of methanolic extract of S.hermanni (Mariyanti, 2017), and tyrosinase inhibitor activity of $S$. hermanni collagen (Safithri et al., 2018). Other explorations of golden sea cucumber or gamat ( $S$. hermanni or $S$. variegatus) from various locations that have been published were studies on collagen extraction (Alhana, Suptijah, \& Tarman, 2015; Fawzya, Chasanah, Poernomo, \& Khirzin, 2016), sulfated glycosaminoglycan content (Masre, Yip, Sirajudeen, \& Ghazali, 2010), angiotensin-I-converting enzyme (ACE) inhibitor and antioxidant activity of collagen peptide (Khirzin et al., 2015), the potential of $S$. hermanii to improve the growth of stem cells (Arundina, Suardita, Setiabudi, \& Ariani, 2016), the effect of sea cucumber extract on the lymphocytes numbers of Wistar rat's oral mucus during the healing process from a traumatic ulcer (Arundina, Yuliati, Soesilawati, Damaiyanti, \& Maharani, 2015); the growth-promoting effect of $S$. variegatus its water extract to boost the proliferation of spinal astrocytes (Patar, Jamalullail, Jaafar, \& Abdullah, 2012) and the ability of sulfated glycosaminoglycan from $S$. hermanni integument in the process of wound healing (Masre et al., 2010).

Sea cucumbers are rich in protein, of which $70 \%$ is collagen with broad applications in producing biomedical, pharmaceutical, body care, and food products (Siddiqui et al., 2013). In the last decade, marine collagens, including sea cucumber collagens and their peptides, have significantly been an interest for study related to their potential biological activity. Various proteases have been reported to produce collagen hydrolysates, including pepsin (Khirzin et al., 2015; Siddiqui et al., 2013), alcalase (Kusumaningtyas, Nurilmala, \& Sibarani, 2019; Safari \& Yaghoubzadeh, 2020); trypsin, papain, bromelain, flavorzyme, and protamex (Forghani et al., 2012). The use of neutrase to hydrolyze sea cucumber collagen from Acaudina molpadioides produced the highest antioxidant activity of hydrolysate compared to those produced using papain, pepsin and trypsin (Jin, Xu, $\mathrm{Li}$, Zhang, \& Xie, 2019). Neutrase was also reported as the best enzyme that produced hydrolysates efficiently with beneficial functional and bioactive characteristics (Liu, Ma, Che, Wang, \& Li, 2018; Ou et al., 2010).

This study was aimed to produce collagen hydrolysates from golden sea cucumber obtained from West Nusa Tenggara using neutrase. The peptide content, molecular weight distribution, and radical scavenging activity of hydrolysate were determined as the important essential figures on utilizing the sea cucumber for antioxidative nutraceuticals.

\section{Material and Methods}

\subsection{Material and Chemicals}

Fresh and dried sea cucumber samples were collected from Labuhan Terata, Sumbawa, West Nusa Tenggara, Indonesia, in February 2017, with $31.88 \pm$ $6.62 \mathrm{~cm}$ in length, $9.42 \pm 2.35 \mathrm{~cm}$ in width, and 796.67 $\pm 334.75 \mathrm{~g}$ in weight each. The samples were washed with freshwater, gutted, washed again and packed into plastic bags. They were then transported (about six hours) in a cool box filled with ice to the laboratory in Jakarta, and then stored at $-20^{\circ} \mathrm{C}$ until used for collagen extraction (for about seven days). Due to the limited fresh samples, dried samples were employed for species identification. The dried samples were obtained from a sea cucumber processor at the same location as the fresh one.

Neutrase ${ }^{\circledR} 0.8 \mathrm{~L}$ (a protease from Bacillus amyloliquefaciens) was supplied by Novozymes (Denmark). SnakeSkin ${ }^{\text {TM }}$ dialysis tubing $10 \mathrm{~K} \mathrm{MWCO}$ was obtained from Thermoscientific (Denmark). DNeasy Blood Tissue Kit was bought from Qiagen (Netherlands) and KOD FX Neo master mix for the PCR was supplied by Toyobo (Japan). DPPH and tryptone casein were obtained from Sigma-Aldrich (Germany). All other chemicals and reagents were pro analysis.

\subsection{Identification of golden sea cucumber}

A dried sea cucumber sample was identified by a molecular method as described by Uthicke, Byrne, and Conand, 2010, which was based on PCR amplification of \pm 675 bp nucleotides from the gene of mitochondrial (COI). COleF: 5'-ATAATGATA GGAGGRTTTGG-3' and COleR: 5'-GCTCGTG 
TRTCTACRTCCAT-3' primers were used to amplify that region (Arndt, Marquez, Lambert, \& Smith, 1996), whereas sequencing was conducted at 1st Base Laboratories (Malaysia). The COI Sequence data were analyzed based on the Basic Local Alignment Search Tool (BLAST). MEGA 7 was used to construct the phylogenetic tree (Kumar, Stecher, \& Tamura, 2016).

\subsection{Chemical Composition of Sea Cucumber}

Chemical composition of sea cucumber was analyzed, including ash content using SNI: 01-2354.12006 (BSN, 2006a), moisture content by SNI 012354.2-2006 (BSN, 2006b), protein by SNI: 01-2354.42006 (BSN, 2006c), and fat content by SNI: 01-2354.32006 (BSN, 2006d).

\subsection{Extraction of Collagen}

The sea cucumber collagen extraction was conducted according to Alhana et al. (2015) with slight modification. All extraction steps were carried out in chilling conditions (approximately $4^{\circ} \mathrm{C}$ ). Previously, samples were cut into small pieces (about $2 \mathrm{~cm} \times 2$ $\mathrm{cm}$ ), immersed, and gently stirred in aquadest (1:5 $\mathrm{w} / \mathrm{v}$ ) for 30 mins, then the water was removed by filtration using a plankton net. Afterward, samples were soaked in 5 volumes $(\mathrm{v} / \mathrm{w})$ of $0.1 \mathrm{M} \mathrm{NaOH}$ solution to remove other proteins. This process was performed while stirred continuously for $48 \mathrm{~h}$. The $\mathrm{NaOH}$ solution was replaced with a fresh on every $24 \mathrm{~h}$. The mixture was then filtered and the sample was washed using aquadest until the remaining washed aquadest had a neutral $\mathrm{pH}$. The resulting mixture was the crude collagen fiber.

The crude collagen was extracted using $0.1 \%$ acetic acid solution (1:5 w/v) for $48 \mathrm{~h}$, followed by filtration. The collagen-containing filtrate was subsequently precipitated by a slow addition of $\mathrm{NaCl}$ powder until the $\mathrm{NaCl}$ final concentration reached 1 $\mathrm{M}$, then kept at $4{ }^{\circ} \mathrm{C}$ for $24 \mathrm{~h}$. The mixture was centrifuged at $15,344 \times g, 4^{\circ} \mathrm{C}$ for 15 mins to produce collagen as the residue material. The next step was dialysis of collagen solution (in $10 \mathrm{~mL} 0.5 \mathrm{M}$ acetic acid) using a 10K-MWCO SnakeSkin ${ }^{\mathrm{TM}}$ dialysis tubing against $1 \mathrm{~L} 0.1 \mathrm{M}$ acetic acid for $12 \mathrm{~h}$. The dialysis solution was changed twice. Finally, the collagen was dialyzed against distilled water for an hour. The dialyzed collagen was centrifuged at $15,344 \times g, 4^{\circ} \mathrm{C}$ for 15 mins, and the pellet as the dialyzed collagen was ready to be hydrolyzed. The yield of crude and dialyzed collagen was calculated as the percentage of each collagen weight to initial fresh sea cucumber weight (\% wet base or $\% \mathrm{wb})$.

\subsection{Hydrolysis of Collagen}

The collagen hydrolysates of sea cucumber were prepared according to Ou et al. (2010). Firstly, collagen was added with $0.01 \mathrm{M}$ phosphate buffer $(\mathrm{pH} 6.7)$ with a ratio of $1: 4(\mathrm{w} / \mathrm{v})$, then digested with $0.5 \%(\mathrm{v} / \mathrm{v})$ neutrase $(4416.8 \mathrm{U} / \mathrm{mL})$. Hydrolysis was done on a hot plate with continuous stirring for $30,60,120,180$, and 240 mins. The hydrolysis process was stopped by heating the mixture in boiling water for 10 mins. The hydrolysates were then separated by centrifugation at $4{ }^{\circ} \mathrm{C} ; 9,820 \times \mathrm{g}$ for 10 mins. Before the analyses, the hydrolysates were dried using a concentrator. The yield of dried collagen hydrolysates was expressed as percentage of dried collagen hydrolysates weight to crude or dialyzed collagen or fresh sea cucumber weight.

\subsection{Determination of Degree of Hydrolysis (DH)}

The degree of hydrolysis was measured using trichloroacetic acid (TCA) precipitation method (Baharuddin, Halim \& Sarbon, 2016) with a slight modification. Approximately $500 \mu \mathrm{L}$ of hydrolysate was added to $500 \mu \mathrm{l}$ of $20 \%$ TCA, homogenized with vortex and kept for 30 mins at $4{ }^{\circ} \mathrm{C}$ to allow precipitation. Nitrogen content of both hydrolysates and supernatants obtained from the hydrolysate treated with TCA (by centrifugation at $4{ }^{\circ} \mathrm{C} ; 7,800 \times g$ for 15 mins) were determined using the Kjeldahl method. The DH was calculated using Equation 1.

$$
\mathrm{DH}(\%)=\frac{\text { Soluble } \mathrm{N} \text { in } 20 \% \mathrm{TCA} \times 100 \%}{\text { Total } \mathrm{N} \text { in the hydrolysate }}
$$

\subsection{Determination of Peptide Content}

The peptide content of collagen hydrolysates was determined by o-phthalaldehyde (OPA) method (Budiari, Chasanah, Suhartono, \& Palupi, 2018). OPA was prepared by mixing $25 \mathrm{~mL}$ of $100 \mathrm{mM}$ sodium tetraborate, $2.5 \mathrm{~mL}$ of $20 \%(\mathrm{w} / \mathrm{v})$ sodium dodecyl sulfate (SDS), $1 \mathrm{~mL}$ OPA solution (40 mg of OPA dissolved in $1 \mathrm{~mL}$ of methanol), $100 \mu \mathrm{L} \alpha-$ mercaptoethanol, and $21.4 \mathrm{~mL}$ distilled water reaching to a final volume of $50 \mathrm{~mL}$. This reagent was prepared daily. A mixture containing $50 \mu \mathrm{L}$ of sample and $2 \mathrm{~mL}$ of OPA solution was kept for 2 mins at ambient temperature, then read the absorbance at $340 \mathrm{~nm}$. Tryptone casein in phosphate buffer $(\mathrm{pH} 7.4)$ with the series of concentrations $0 ; 0.1 ; 0.5 ; 1$ and $2 \mathrm{mg} / \mathrm{mL}$ was used as a standard curve to determine peptide content. 


\subsection{Molecular Weight Analysis}

The molecular weight of collagen was described using sodium dodecyl sulfate-polyacrylamide gel electrophoresis (SDS-PAGE) method (Bollag, Rozycki, \& Edelstein, 1996). Collagen $(15 \mu \mathrm{L})$ was mixed with the sample loading buffer $(5 \mu \mathrm{L})$ and boiled before loading to $4 \%$ separating and $10 \%$ resolving gel. Low molecular weight markers (LMW) with a range of 14.4-97 kDa and high molecular weight markers (HMW) with a range of $53-220 \mathrm{kDa}$ (GE Healthcare, USA) were used as a marker. The electrophoresis was conducted for approximately $2 \mathrm{~h}$ at a constant voltage of $125 \mathrm{~V}$. The gel was stained with Coomassie blue staining.

\subsection{Determination of Antioxidant Activity}

The antioxidant activity of the collagen hydrolysates was analyzed based on DPPH radical scavenging activity, according to Khirzin et al. (2015) with modification. The hydrolysates were dried using a vacuum concentrator. Stock solution $(20 \mathrm{mg} / \mathrm{mL})$ was firstly prepared by dissolving $20 \mathrm{mg}$ sample in one milliliter phosphate buffer $(\mathrm{pH} 7)$ because the sample did not completely dissolve in methanol. A series concentration of samples $(1 ; 2 ; 4 ;$ and $8 \mathrm{mg} / \mathrm{mL})$ was prepared by diluting the stock solution using methanol. Each sample $(160 \mu \mathrm{L})$ was placed into the 96-well microplate and added with $40 \mu \mathrm{l}$ of $0.78 \mathrm{mM} \mathrm{DPPH}$ solution (methanol as solvent). The mixture was incubated at ambient temperature for 30 mins in the dark room and measured their absorbance at $517 \mathrm{~nm}$. The negative control used was methanol with DPPH addition, methanol solution was used as blank, whereas ascorbic acid with a concentration of 0.008 $\mathrm{mg} / \mathrm{mL}$ was used as the positive control. The DPPH radical scavenging activity (\%) was calculated using Equation 2.

DPPH radical scavenging activity $(\%)=\left[\frac{((\text { Ac- }(\text { As- }-A b))}{A c}\right] \times 100 \%$

Where Ac is the absorbance of the control reaction, As is the absorbance of the sample, and $A b$ is the absorbance of the blank solution.

\subsection{Statistical Analysis}

All analyses of the collagen hydrolysates were carried out in duplicates. The data were presented as the mean \pm SD and analyzed by one-way ANOVA with a significance level at $p<0.05$. The Duncan test was used to determine significant differences at the $5 \%$ probability level.

\section{Results and Discussion}

\subsection{Identification of Sea Cucumber}

The result of the phylogenetic analyses (Figure1) showed that the golden sea cucumber used in this study, coded as NF $1 \mathrm{Gab}$ and NF $2 \mathrm{Gab}$, had similarities with $S$. horrens and $S$. monotuberculatus. The COI similarity result generated by BLAST analysis indicated that the similarity was $99 \%$. This result supported Purcell et al. (2012) findings that $S$. horrens, S. monotuberculatus, S. quadrifasciatus, and S. naso are often indistinguishable due to their similar appearances. The local name golden sea cucumber or "teripang emas" are commonly known as $S$. variegatus which are found in some publications (Adriansyah \& Sulastri, 2014; Cahyati et al., 2018) or S. hermanni (Arundina et al., 2015; Damaiyanti, 2015; Safithri et al., 2018; Susanto, Savitrim, \& Tarman, 2018). However, it was also reported that the $S$. hermanni was previously known as $S$. variegatus (Pangestuti \& Arifin, 2018). The present study gave different results that the golden sea cucumber obtained from Lombok island, West Nusa Tenggara was closer to $S$. horrens and S. monotuberculatus. The previous study showed that a phylogenetic tree constructed by the same method has successfully separated S. horrens, S. hermanni, and $S$. monotuberculatus (Patantis et al., 2019), which proved that the phylogenetic tree of $\mathrm{COI}$ sequences could also differentiate Stichopus at the species level.

\subsection{Chemical Composition of Sea Cucumber and Yield of Collagen}

The sea cucumber chemical composition used in this study is presented in Table 1, along with the proximate composition of other Stichopus sp. that had been reported previously. The wet base (wb) data was converted into the dry base (db) for comparison purpose. It is shown that the sea cucumber moisture and protein contents used in this study are similar to those of other species of Stichopus. At the same time, the fat content of the sample was relatively lower $(<$ $2 \% \mathrm{db}$ ) compared to that of other $S$. horrens as well as other Stichopus sp. reported. This result was used as a preliminary data for non-alcohol pre-treatment in the collagen extraction to remove fat instead of those conducted by Fawzya et al. (2016) and Nagai, Tanoue, Kai, and Suzuki (2015). The moisture, ash, protein and fat contents of Stichopus varied from 90.86 to $95.14 ; 31.69$ to $56.12 ; 30.73$ to 54.32 and 1.46 to $4.89 \%$, respectively. The high ash content might be attributed to the high content of minerals and other 


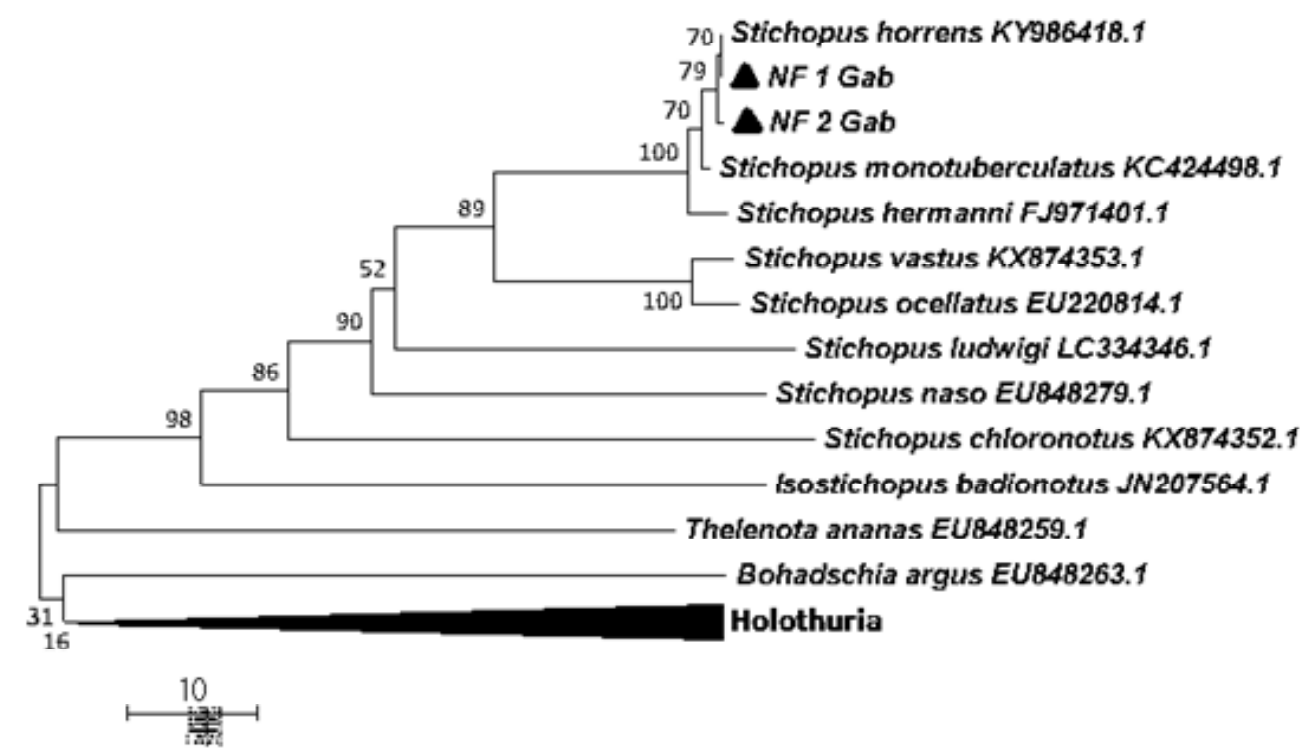

Figure.1. The phylogenetic tree of golden sea cucumber beche-de-merfrom Lombok island, coded as NF 1 Gab and NF 2 Gab. The tree was created using the neighbor-joining method by testing bootstrap of 1000 replications. The numbers shown next to the branches showed bootstrap values.

Table 1. Chemical composition of golden sea cucumber

\begin{tabular}{|c|c|c|c|c|c|c|}
\hline No & $\begin{array}{c}\text { Sea } \\
\text { cucumbers }\end{array}$ & $\begin{array}{c}\text { Moisture } \\
\text { (\% wb) }\end{array}$ & $\begin{array}{c}\text { Ash } \\
(\% d b)\end{array}$ & $\begin{array}{c}\text { Protein } \\
(\% \mathrm{db})\end{array}$ & $\begin{array}{c}\text { Fat } \\
(\% d b)\end{array}$ & Ref \\
\hline 1 & S. horrens & $94.51 \pm 0.03$ & $55.01 \pm 0.08$ & $34.97 \pm 0.25$ & $1.46 \pm 0.03$ & Present study \\
\hline 2 & S. horrens & 93.10 & $39.13^{*}$ & $41.01^{*}$ & $3.04^{*}$ & Forghani et al., 2012 \\
\hline 3 & S. horrens & 95.14 & $31.69^{*}$ & $36.62^{*}$ & $4.11^{*}$ & Gianto et al., 2017 \\
\hline 4 & S. herrmanni & $92.74 \pm 0.36$ & $40.94 \pm 2.55$ & $30.73 \pm 2.40$ & $4.89 \pm 0.24$ & Mariyanti, 2017 \\
\hline 5 & S. variegatus & $91.19 \pm 0.07$ & $40.18 \pm 1.93$ & $54.32 \pm 0.68$ & $2.72 \pm 0.23$ & Fawzya et al., 2016 \\
\hline 6 & S. variegatus & $93.84 \pm 0.09$ & $43.18 \pm 1.95^{\star}$ & $43.67 \pm 0.49^{\star}$ & $2.92 \pm 0.10^{*}$ & Alhana et al., 2015 \\
\hline 7 & S. ocellatus & 93.80 & $56.12^{*}$ & $35.32^{*}$ & $3.06^{*}$ & Rasyid \& Ardiansyah, 2016 \\
\hline 8 & $\begin{array}{l}\text { Apostichopus } \\
\text { japonicus }\end{array}$ & $90.86-91.19$ & $32.22-33.90$ & $45.12-46.10$ & $3.87-5.11$ & Wu et al., 2015 \\
\hline
\end{tabular}

${ }^{*}$ Converted into \%db

inorganic matter in the sea cucumber's body wall. It might be related to skeletal elements, called ossicles, within cellular vesicles of the sea cucumber's body wall (Blowes et al., 2017). Ossicles are composed mainly of calcium carbonate (Bechtel, Oliveira, Demir, \& Smiley, 2013). Variation of each species' proximate composition might be affected by several factors, such as seasonal variations, geographical location, and feeding system (Oh, Ko, Lee, Heo, \& Jung, 2017; Santos et al., 2015). Procedures of handling also could influence sea cucumbers' chemical composition (Özer, Mol, \& Varlýk, 2005).
Collagen extraction from the golden sea cucumber produced of $16.70 \%$ of crude collagen (\% wb) or $7.20 \%$ of dialyzed collagen (\% wb) (Table 2$)$. After being hydrolyzed by neutrase, dried collagen hydrolysates' yield was in the range of $0.83-0.88 \%$ (\% wb) or equivalent to $15.12-16.03 \%$ (\% db). Other research showed that dried collagen extracted from $S$. vastus and $H$. atra produced yield of $0.92 \%$ and $0.88 \%$ wb (Yuniati \& Sulardiono, 2019). Meanwhile, the dried collagen extracted from golden sea cucumber $(S$. hermanii) had a lower yield, i.e., $0.66 \%$ (Safithri et al., 2018). In this research, the dialyzed collagen was 
Table 2. Yields of crude collagen, dialyzed collagen and collagen hydrolysates extracted from the body wall of golden sea cucumber*

\begin{tabular}{lcc}
\hline \multicolumn{1}{c}{ Product } & Yield $(\% \text { wb })^{1}$ & Yield $(\% \text { wb })^{2,3}$ \\
\hline Crude collagen $^{1}$ & $16.70 \pm 4.24$ & \\
Dialyzed collagen ${ }^{1,2}$ & $7.20 \pm 0.36$ & $44.27 \pm 9.12$ \\
Collagen hydrolysates & & \\
from hydrolysis time \\
$(\mathrm{min})^{1,3}:$
\end{tabular}

\footnotetext{
${ }^{*}$ Analyzed using one-way ANOVA

a-bDifferent letters show significant differences in the same column $(p<0.05)$

1) percentage of fresh sea cucumber

2) percentage of crude collagen

3) percentage of dialyzed collagen
}

directly hydrolyzed by neutrase without drying. The difference yield was most likely related to the variation method of collagen extraction and sea cucumber species as the source of collagen. In this work we omitted several pre-treatment steps to improve product yield and process efficiency. Collagen extraction consists of several steps, including pretreatment using certain chemicals intended to remove non-collagen protein, fats and other impurities. The difference of collagen yield was probably affected by the chemical concentration, ratio of the substance to the solvent and the extract separation method. The inappropriate concentration, ratio and separation method (such as centrifuge, pressing or filtering using a specific size of planktonet) will reduce the extraction effectiveness, which further produces a lower yield.

\subsection{Degree of Hydrolysis (DH) and Peptide Content}

The level of collagen cleavage of golden sea cucumber by neutrase was described on the degree of hydrolysis results and peptide content. The degree of hydrolysis $(\mathrm{DH})$ is defined as the proportion of peptides bond digested to the total peptides bond. Figure 2 shows that $\mathrm{DH}$ increases rapidly in the first hour of hydrolysis, then the rate declined slowly in the following hours. DH's rise showed that a quantity of free amino groups of the protein increased and the change of protein molecular weight occurred. The highest $\mathrm{DH}$ was achieved after 180 mins of hydrolysis, reaching $55.2 \%$ of $\mathrm{DH}$ value $(p<0.05)$. After three hours, the $\mathrm{DH}$ decreased because of the product inhibition and/or enzyme denaturation.

It was reported that the hydrolysis of $S$. horrens' tissue was more effective when using alkalase than other proteases (Forghani et al., 2012). This enzyme $(2103 \mathrm{U} / \mathrm{mL})$ produced the highest $\mathrm{DH}(39.8 \%)$ in 200 mins and the hydrolysate had the highest ACE inhibitory activity. The use of neutrase with the total activity of $2.01 \times 10^{5} \mathrm{U}$ produced $\mathrm{DH}$ of Alaska pollock hydrolysates of approximately. $25 \%$ and reached equilibrium at 160 mins hydrolysis (Liu et al., 2018). They stated that neutrase was the most efficient enzyme to improve protein solubility compared to six food-grade proteases. It seems that $\mathrm{DH}$ resulting from the hydrolysis process was affected by the type and concentration of enzymes as well as type of substrates.

The increase of $\mathrm{DH}$ was followed by peptide increment (Figure 3) due to the release of peptides as a result of neutrase activity during the hydrolysis process. The correlation test exhibited that peptide content was strongly correlated to $\mathrm{DH}\left(R^{2} 0.79\right.$, data not shown). However, the increment of peptide content was insignificant after 180-mins of hydrolysis, reaching $12.79 \pm 0.44 \mathrm{mg} / \mathrm{mL}$ of peptides. This might be related 


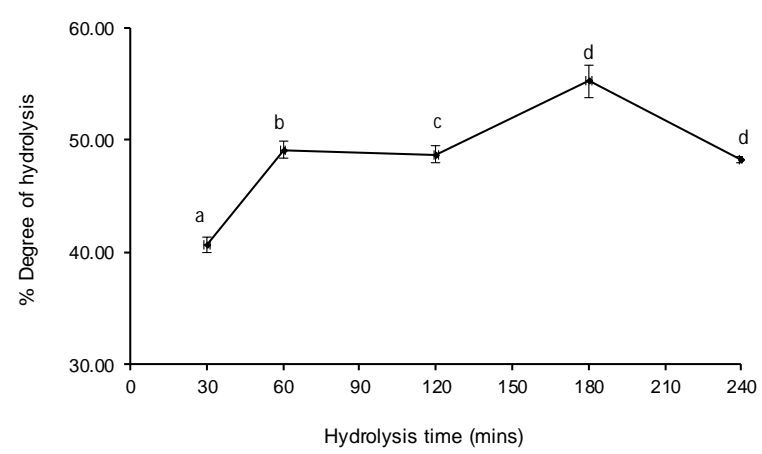

Figure 2. Degree of hydrolysis of collagen hydrolysates produced from golden sea cucumber

to one (or more) of these reasons: the decrease of enzyme activity to hydrolyze substrate (collagen hydrolysate), the reduction in the amount of accessible peptide bonds as the substrate to be digested or inhibition of the hydrolyzed product to the remaining substrate (Guérard, Dufossé, De La Broise \& Binet, 2001). Putalan, Munifah, Nurhayati and Chasanah (2018) reported the similar pattern that the highest DH and peptides on hydrolysis of striped trevally fish (Selaroides leptolepis) using $B$. licheniformis protease was reached after six hours of hydrolysis.

\subsection{Molecular Weight Distribution}

The SDS-PAGE profile generated from the hydrolysates is presented in Figure 4. It is indicated that the initial unhydrolyzed collagen (line 1) showed a thick and clear band with a size of approx. $220 \mathrm{kDa}$. The addition of neutrase hydrolyzed collagen rapidly resulted in hydrolysates with molecular weight ranging from less than $14.4 \mathrm{kDa}$ to $53 \mathrm{kDa}$. Hydrolysis for 30 mins exhibited three visible thin bands with the size of approx. 53; 45 and $25 \mathrm{kDa}$, meanwhile $1 \mathrm{~h}$ hydrolysis produced hydrolysates with molecular weight of 25; 14.4 and under $14.4 \mathrm{kDa}$. The band almost completely disappeared after two hours of hydrolysis. This is probably related to the neutrase as a neutral endopeptidase which randomly digests peptide bonds of non-terminal amino acids (Anonymous, 2016) and aids other protein hydrolysis (Hong, Min, \& Jo, 2019). The decrease of molecular weight occurred in accordance with the hydrolysis time.

This pattern was similar to the molecular weight distribution of porcine skin collagen hydrolysates treated with neutrase (Hong et al., 2019). They investigated hydrolysate produced from the hydrolysis process with the enzyme:substrate ratio of $1: 100$ had disappeared entirely after six hours of incubation. They

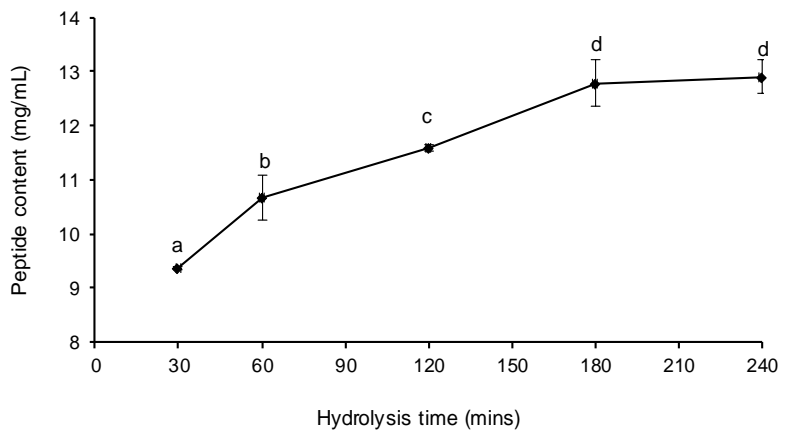

Figure 3. Peptide content of collagen hydrolysates produced from golden sea cucumber

further mentioned that protease type, hydrolysis time and the ratio of enzyme/substrate affected the digestion pattern of protein into peptides and amino acids. Liu et al. (2018) observed that complete degradation of the Alaska pollock protein isolate by neutrase occurred at 40 to 240 mins of hydrolysis with the average molecular weights produced were less than $10 \mathrm{kDa}$. At the final hydrolysis time $(240$ mins), small peptides (500 Da) were produced. According to Hong et al. (2019), molecular weight exhibited a level of fractionation. A fraction with MW of $<3 \mathrm{kDa}$ indicates a collagen hydrolysate; a fraction with MW greater than $50 \mathrm{kDa}$ is gelatin; and a fraction with MW greater than $300 \mathrm{kDa}$ is collagen. Thus, a lower molecular weight marker (less than $10 \mathrm{kDa}$ ) is necessary for SDS-PAGE or HPLC analysis for precise results.

\subsection{Antioxidant Activity}

The activity of collagen hydrolysate produced by the golden sea cucumber was assayed by the DPPH radical scavenging activity method with the concentration of $1 ; 2 ; 4$ and $8 \mathrm{mg} / \mathrm{mL}$. Ascorbic acid was used as a positive control with the concentration of $0.004 ; 0.006 ; 0.008$ and $0.010 \mathrm{mg} / \mathrm{mL}$. The results showed that the antioxidant activity of samples were increased in a concentration-dependent manner. Further determination of $\mathrm{IC}_{50}$ indicated that the hydrolysate produced from 60-min hydrolysis had the lowest IC ${ }_{50}(5.25 \pm 0.15 \mathrm{mg} / \mathrm{mL})$ those that of the other hydrolysates, which means that the antioxidant activity was the highest. However, the $\mathrm{IC}_{50}$ value was still much higher than that of ascorbic acid $(0.0082 \pm 0.0001$ $\mathrm{mg} / \mathrm{mL}$ ) as control. The antioxidant activity of ascorbic acid, equivalent with $46.5 \mu \mathrm{M}$ (MW of $176.12 \mathrm{Da}$ ), was 4.5 up to 8-fold than that of collagen hydrolysate produced from 60 -min hydrolysis ( 210 and $375 \mu \mathrm{M}$, respectively) with an estimated molecular weight of 25 and $14 \mathrm{kDa}$ (Figure 4). Thus, the collagen 


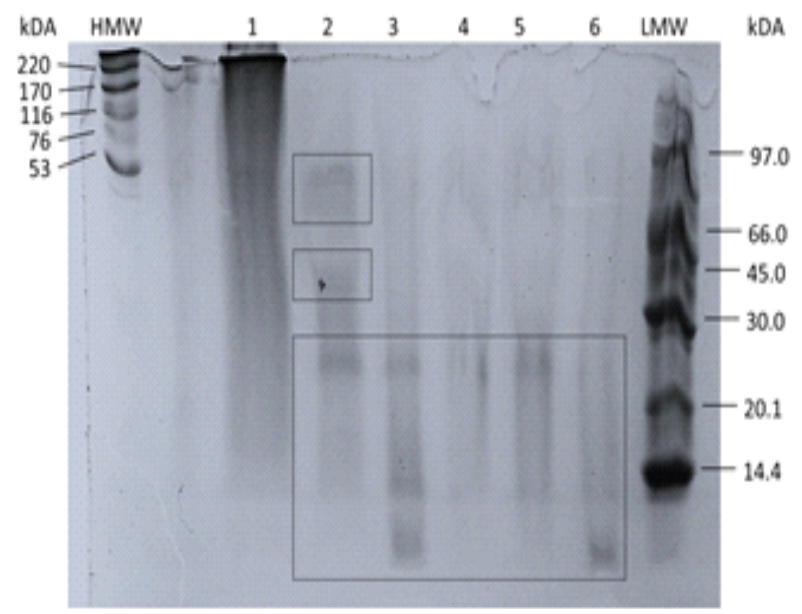

Figure 4. Molecular size distribution profile of golden sea cucumber collagen hydrolysates produced by neutrase hydrolysis. HMW: High Molecular Weight; 1: Unhydrolyzed collagen; 2: Hydrolysis 30 min; 3: Hydrolysis 60 min; 4: Hydrolysis 120 min; 5: Hydrolysis 180 min; 6: Hydrolysis 240 min; LMW: Low Molecular Weight. SDS-PAGE was done using a separating gel concentration of $15 \%$ at 125 Volt

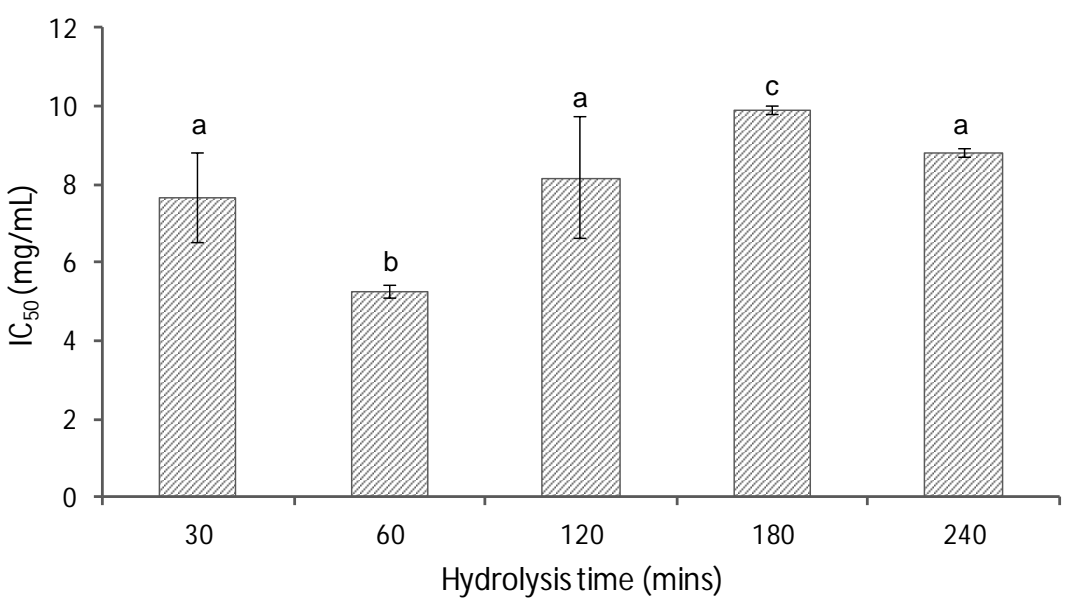

Figure 5. Antioxidant activity of collagen hydrolysates derived from golden sea cucumber (mean values with different letters indicate significant differences $(p<0.05))$

hydrolysate may be classified as a weak to moderate antioxidant, even though there is no classification for $\mathrm{IC}_{50}$ values that can be referred.

To date, protein hydrolysates with strong antioxidant activity are rarely reported. However, low MW protein hydrolysates from yellowfin tuna skin (3$10 \mathrm{kDa}$ ) and the spotted Babylon snail ( $3-5 \mathrm{kDa}$ ) were reported as potent antioxidants with $\mathrm{IC}_{50}$ of $75.94 \mu \mathrm{g} /$ $\mathrm{mL}$ and $2.69 \mu \mathrm{g} / \mathrm{mL}$, respectively (Nurilmala, Hizbullah, Karnia, Kusumaningtyas, \& Ochiai, 2020; Petsantad et al., 2020). Liu et al. (2018) investigated that hydrolysis of the Alaska pollock protein isolate using neutrase significantly improved the DPPH free radicalscavenging activity. The inhibition of $5 \mathrm{mg} / \mathrm{mL}$ hydrolysate produced from 240-min incubation reached $85.22 \%$. They further found that the longer the hydrolysis time, the lower the molecular weight and the higher the antioxidant activity. In this study, the highest antioxidant activity exhibited by hydrolysate produced from 60-mins hydrolysis with the $\mathrm{DH}$ reached $49.11 \%$ and peptide content of $10.67 \mathrm{mg} / \mathrm{mL}$. The probable reason was that the amino acid composition and sequence contributed to the antioxidant activity were present higher in the 60 -min hydrolysate than those in the other counterparts.

According to You, Zhao, Regenstein, \& Ren (2010), hydrophobic amino acids and residues of proline, cysteine, methionine, histidine, tyrosine, phenylalanine, and tryptophan could improve the antioxidant activity of peptides available in fish protein hydrolysates. Other factors that may affect the inhibitory activities of protein hydrolysates, including 
size and structure of peptides, $\mathrm{DH}$, molecular weight, etc. (Cheung, Cheung, Tan, \& Li-Chan, 2012; Raghavan \& Kristinsson, 2008). DPPH radical is a stable compound that can react with various antioxidants. The DPPH method is also simple and relatively inexpensive, making it used broadly to determine the antioxidant activity of many samples from various resources (Santos-Sánchez, Salas-Coronado, Villanueva-Cañongo, \& Hernández-Carlos, 2019).

\section{Conclusion}

Golden sea cucumber obtained from West Nusa Tenggara was identified as Stichopus horrens or S. monotuberculatus. The sea cucumber collagen hydrolysis using neutrase produced hydrolysates with molecular weight less than $53 \mathrm{kDa}$ and smaller peptide products in line with the increase of hydrolysis time. The hydrolysate produced after 60 mins of hydrolysis demonstrated the highest radical scavenging activity with $\mathrm{IC}_{50}$ of $5.25 \pm 0.15 \mathrm{mg} / \mathrm{mL}$ that might be classified as a weak to moderate antioxidant. However the highest $\mathrm{DH}$ and peptides were produced after $180 \mathrm{mins}$ of hydrolysis.

\section{Acknowledgments}

This research was funded by the State Budget (APBN) for the Research Center for Marine and Fisheries Product Processing and Biotechnology in 2017, No. SP DIPA-032.12.2.403835/2017. We thank PT Brenntag, Jakarta, for the neutrase provided for this research.

\section{References}

Adriansyah, H. A., \& Sulastri, H. S. (2014). Efek Hepatoprotektif Teripang Emas (Stichopus variegatus) pada Tikus Jantan Dewasa Galur Wistar yang Diinduksi Parasetamol Dosis Toksik. Majalah Kedokteran Sriwijaya, 46(2), 136-143. doi: 10.36706/ mks.v46i2.2695

Alhana, A., Suptijah, P., \& Tarman, K. (2015). Extraction and Characterization of Collagen from Sea Cucumber Flesh. Jurnal Pengolahan Hasil Perikanan Indonesia, 18(2), 150-161. doi: 10.17844/ jphpi.2015.18.2.150

Anonymous (2016). Proteases for biocatalysis. Novozymes.

Arndt, A., Marquez, C., Lambert, P., \& Smith, M. J. (1996). Molecular phylogeny of eastern Pacific sea cucumbers (Echinodermata: Holothuroidea) based on mitochondrial DNA sequence. Molecular Phylogenetics and Evolution, 6(3), 425-437. doi: 10.1006/mpev.1996.0091

Arundina, I., Suardita, K., Setiabudi, H., \& Ariani, M. D. (2016). Golden sea cucumbers (Stichopus Hermanii) as growth factors of stem cells. Journal of International Dental and Medical Research, 9(3), 242-248.

Arundina, I., Yuliati, Y., Soesilawati, P., Damaiyanti, D. W., \& Maharani, D. (2015). The effects of golden sea cucumber extract (Stichopus hermanii) on the number of lymphocytes during the healing process of traumatic ulcer on wistar rat's oral mucous. Dental Journal (Majalah Kedokteran Gigi), 48(2), 100. doi: 10.20473/j.djmkg.v48.i2.p100-103

Baharuddin, N. A., Halim, N. R. A., \& Sarbon, N. M. (2016). Effect of degree of hydrolysis (DH) on the functional properties and angiotensin I-converting enzyme (ACE) inhibitory activity of eel (Monopterus sp.) protein hydrolysate. International Food Research Journal, 23(4), 1424-1431.

Bechtel, P. J., Oliveira, A. C. M., Demir, N., \& Smiley, S. (2013). Chemical composition of the giant red sea cucumber, Parastichopus californicus, commercially harvested in Alaska. Food Science \& Nutrition, 1(1), 63-73. doi: 10.1002/fsn3.12

Blowes, L. M., Egertová, M., Liu, Y., Davis, G. R., Terrill, N. J., Gupta, H. S., \& Elphick, M. R. (2017). Body wall structure in the starfish Asterias rubens. Journal of Anatomy, 231(3), 325-341. doi: 10.1111/joa.12646

Bollag, D. M., Rozycki, M. D., \& Edelstein, S. J. (1996). Protein Methods - 2nd edition. Wiley-Liss, 432.

Bordbar, S., Anwar, F., \& Saari, N. (2011). High-value components and bioactives from sea cucumbers for functional foods-a review. Marine Drugs, 9(10), 1761-1805. doi: 10.3390/md9101761

Badan Standar Nasional (BSN). (2006a). Cara uji kimiaBagian 1: Penentuan Kadar Abu pada Produk Perikanan. SNI: 01-2354.1-2006. Jakarta (ID). BSN.

Badan Standar Nasional (BSN). (2006b). Cara uji kimiaBagian 2: Penentuan kadar air pada produk perikanan. SNI 01-2354.2-2006. Jakarta (ID). BSN.

Badan Standar Nasional (BSN). (2006c). Cara uji kimiaBagian 3: Penentuan kadar lemak pada produk perikanan. SNI 01-2354.3-2006. Jakarta (ID). BSN.

Badan Standar Nasional (BSN). (2006d). Cara uji kimiaBagian 4: Penentuan kadar protein pada produk perikanan. SNI 01-2354.4-2006. Jakarta (ID). BSN.

Budiari, S., Chasanah, E., Suhartono, M. T., \& Palupi, N. S. (2018). Angiotensin converting enzyme (ACE) inhibitory activity of crude and fractionated snakehead (Channa striata) meat extract. Squalen Bulletin of Marine and Fisheries Postharvest and Biotechnology, 13(2), 57. doi: 10.15578/squalen.v13i2.345

Cahyati, M., Rahmawati, P. A. A., Kusuma, N., \& Adam, S. A. (2018). Pemanfaatan antioksidan (glutathione) teripang emas laut (Golden Stichopus variegatus) berbasis nanoteknologi dalam apoptosis sel skuamosa kanker mulut. E-Prodenta Journal of Dentistry, 2(2), 149-154. doi: 10.21776/ub.eprodenta. 2018.002.02.2

Cheung, I. W. Y., Cheung, L. K. Y., Tan, N. Y., \& Li-Chan, E. C. Y. (2012). The role of molecular size in antioxidant activity of peptide fractions from Pacific hake (Merluccius productus) hydrolysates. Food Chemistry, 
134(3), 1297-1306. doi:10.1016/j.foodchem. 2012.02.215

Damaiyanti, D. W. (2015). Karakterisasi ekstrak air teripang emas (Stichopus hermanii). DENTA Jurnal Kedokteran Gigi, 9(1), 74-81. doi: 10.30649/ denta.v9i1.19

Dewi, A. S., Patantis, G., Fawzya, Y. N., Irianto, H. E., \& Sa'diah, S. (2020). Angiotensin-converting enzyme (ace) inhibitory activities of protein hydrolysates from indonesian sea cucumbers. International Journal of Peptide Research and Therapeutics, 26: 2485-2493. doi: 10.1007/s10989-020-10035-5

Fad'ha, G., Arma, U., \& Busman, B. (2019). Uji aktivitas antibakteri ekstrak teripang gamat (Stichopus variegatus) dari Kepulauan Mentawai terhadap Bakteri Streptococcus viridans. B-Dent, Jurnal Kedokteran Gigi Universitas Baiturrahmah, 4(1), 5260. doi: $10.33854 / j b d j b d .89$

Fawzya, Y. N., Chasanah, E., Poernomo, A., \& Khirzin, M. $H$. (2016). Isolasi dan karakterisasi parsial kolagen dari teripang gamma (Stichopus variegatus). Jurnal Pascapanen Dan Bioteknologi Kelautan Dan Perikanan, 11(1), 91-100. doi:10.15578/ jpbkp.v11i1.284

Forghani, B., Ebrahimpour, A., Bakar, J., Abdul Hamid, A., Hassan, Z., \& Saari, N. (2012). Enzyme hydrolysates from Stichopus horrens as a new source for angiotensin-converting enzyme inhibitory peptides. Evidence-Based Complementary and alternative Medicine, 2012. doi: 10.1155/2012/236384

Guérard, F., Dufossé, L., De La Broise, D., \& Binet, A. (2001). Enzymatic hydrolysis of proteins from yellowfin tuna (Thunnus albacares) wastes using alcalase. Journal of Molecular Catalysis-B Enzymatic, 11(46), 1051-1059. doi: 10.1016/S1381-1177(00)00031$\mathrm{X}$

Hong, G. P., Min, S. G., \& Jo, Y. J. (2019). Antioxidative and anti-aging activities of porcine by-product collagen hydrolysates produced by commercial proteases: Effect of hydrolysis and ultrafiltration. Molecules, 24(6): 1104. doi: 10.3390/molecules24061104

Jin, H. X., Xu, H. P., Li, Y., Zhang, Q. W., \& Xie, H. (2019). Preparation and evaluation of peptides with potential antioxidant activity by microwave assisted enzymatic hydrolysis of collagen from sea cucumber Acaudina molpadioides obtained from Zhejiang province in China. Marine Drugs, 17(3): 169. doi: 10.3390/md 17030169

Khirzin, M. H., Sukarno, S., Yuliana, N. D., Fawzya, Y. N., \& Chasanah, E. (2015). Aktivitas Inhibitor Enzim Pengubah Angiotensin (ACE) dan Antioksidan Peptida Kolagen dari Teripang Gama (Stichopus variegatus). Jurnal Pascapanen Dan Bioteknologi Kelautan Dan Perikanan, 10(1), 27. doi: 10.15578/ jpbkp.v10i1.242

Kumar, S., Stecher, G., \& Tamura, K. (2016). MEGA7: Molecular Evolutionary Genetics Analysis Version 7.0 for Bigger Datasets. Molecular Biology and Evolution, 33(7), 1870-1874. doi: 10.1093/molbev/msw054
Kusumaningtyas, E., Nurilmala, M., \& Sibarani, D. (2019). Antioxidant and antifungal activities of collagen hydrolysates from skin of milkfish (Chanos chanos) hydrolyzed using various bacillus proteases. IOP Conference Series: Earth and Environmental Science, 278(1): p. 012040. doi: 10.1088/1755-1315/278/1/ 012040

Liu, C., Ma, X., Che, S., Wang, C., \& Li, B. (2018). The effect of hydrolysis with neutrase on molecular weight, functional Properties, and antioxidant Activities of Alaska pollock protein isolate. Journal of Ocean University of China, 17(6), 1423-1431. doi: 10.1007/ s11802-018-3649-9

Mariyanti. (2017). Kandungan kimia dan aktivitas penghambatan alfa-glukosidase secara in vitro dari ekstrak methanol Stichopus hermanii dan Spirulina platensis. Skripsi FMIPA-IPB.

Masre, S. F., Yip, G. W., Sirajudeen, K. N. S., \& Ghazali, F. C. (2010). Wound healing activity of total sulfated glycosaminoglycan (GAG) from Stichopus vastus and Stichopus hermanni integumental tissue in rats. International Journal of Molecular Medicine and Advance Sciences, 6(4), 49-53.

Nagai, T., Tanoue, Y., Kai, N., \& Suzuki, N. (2015). Characterization of collagen from emu (Dromaius novaehollandiae) skins. Journal of Food Science and Technology, 52(4), 2344-2351. doi: 10.1007/s13197014-1266-1

Nurilmala, M., Hizbullah, H. H., Karnia, E., Kusumaningtyas, E., \& Ochiai, Y. (2020). Characterization and antioxidant activity of collagen, gelatin, and the derived peptides from yellowfin tuna (Thunnus albacares) Skin. Marine Drugs, 18(2). doi: $10.3390 / \mathrm{md} 18020098$

Nursid, M., Marraskuranto, E., Kuswardini, A., \& Winanto, T. (2019). Screening of tyrosinase inhibitor, antioxidant and cytotoxicity of dried sea cucumber from Tomini Bay, Indonesia. Pharmacognosy Journal, 11(3), 555558. doi: 10.5530/pj.2019.11.88

Oh, G. W., Ko, S. C., Lee, D. H., Heo, S. J., \& Jung, W. K. (2017). Biological activities and biomedical potential of sea cucumber (Stichopus japonicus): A review. Fisheries and Aquatic Sciences, 20(1), 1-17. doi: 10.1186/s41240-017-0071-y

Ou, K., Liu, Y., Zhang, L., Yang, X., Huang, Z., Nout, M. R., \& Liang, J. (2010). Effect of neutrase, alcalase, and papain hydrolysis of whey protein concentrates on iron uptake by Caco-2 cells. Journal of Agricultural and Food Chemistry, 58(8), 4894-4900. doi: 10.1021/ jf100055y

Özer, N. P., Mol, S., \& Varlýk, C. (2005). Effect of the Handling Procedures on the Chemical Composition of Sea Cucumber. Turkish Journal of Fisheries and Aquatic Sciences, 74(2004), 71-74.

Pangestuti, R., \& Arifin, Z. (2018). Medicinal and health benefit effects of functional sea cucumbers. Journal of Traditional and Complementary Medicine, 8(3), 341-351. doi: 10.1016/j.jtcme.2017.06.007

Pangestuti, R., Murniasih, T., Putra, M. Y., Rasyid, A., Wibowo, J. T., Ardiansyah, A., \& Untari, F. (2016). Free 
radical scavenging activity of selected sea cucumber species from Mataram-Lombok, Indonesia. Jurnal Teknologi, 78(4-2), 179-185. doi:10.11113/jt. v78.8202

Patantis, G., Dewi, A., Fawzya, Y., \& Nursid, M. (2019). Identification of Beche-de-mers from Indonesia by molecular approach. Biodiversitas, 20(2), 537-543. doi: 10.13057/biodiv/d200233

Patar, A., Jamalullail, S. M. S. S., Jaafar, H., \& Abdullah, J. M. (2012). The effect of water extract of sea cucumber Stichopus variegatus on rat spinal astrocytes cell lines. Current Neurobiology, 3(1), 11-16.

Purcell, S. W., Y. Samyn, \& C. Conand. Commercially important sea cucumbers of the world. Rome, Italy: FAO. No. 6. Report, 2012.

Putalan, R., Munifah, I., Nurhayati, T., \& Chasanah, E. (2018). Antioxidant and Ace Inhibitor Potential of Stripe Trevally Fish (Selaroides leptolepis) Hydrolysate. Squalen Bulletin of Marine and Fisheries Postharvest and Biotechnology, 13(1), 17. doi: 10.15578/ squalen.v13i1.319

Raghavan, S., \& Kristinsson, H. G. (2008). Antioxidative efficacy of alkali-treated tilapia protein hydrolysates: A comparative study of five enzymes. Journal of Agricultural and Food Chemistry, 56(4), 1434-1441. doi: $10.1021 /$ jf0733160

Safari, R., \& Yaghoubzadeh, Z. (2020). Antioxidant Activity of Bioactive Peptides Extracted from Sea Cucumber (Holothuria leucospilata). International Journal of Peptide Research and Therapeutics, (2016), 1-6. doi: 10.1007/s10989-020-10031-9

Safithri, M., Setyaningsih, I., Tarman, K., Yuhendri, V. M., \& Meydia, M. (2018). Potensi Kolagen Teripang Emas Sebagai Inhibitor Tirosinase. Jurnal Pengolahan Hasil Perikanan Indonesia, 21(2), 296. doi: org/ 10.17844/jphpi.v21i2.23085
Santos-Sánchez, N. F., Salas-Coronado, R., VillanuevaCañongo, C., \& Hernández-Carlos, B. (2019). Antioxidant compounds and their antioxidant mechanism. In E. Shalaby (Ed.), Antioxidant. IntechOpen. doi: 10.5772/intechopen.85270

Santos, R., Dias, S., Pinteus, S., Silva, J., Alves, C., Tecelão, C., ... Pedrosa, R. (2015). The biotechnological and seafood potential of Stichopus regalis. Advances in Bioscience and Biotechnology, 6(3), 194-204. doi: 10.4236/abb.2015.63019

Siddiqui, Y., Arief, E., Yusoff, A., Hamid, S., Norani, T., \& Abdullah, M. (2013). Extraction, purification and physical characterization of collagen from body wall of sea cucumber Bohadschia bivitatta. Health and the Environment Journal, 4(2), 53-65.

Susanto, H., Savitrim, M., \& Tarman, K. (2018). Antibacterial activity of Stichopus hermanii and Stichopus variegatus methanol extract. Current Biochemistry, 4(2), 1-11. doi: 10.29244/cb.4.2

Uthicke S., Byrne M., \& Conand C. (2010). Genetic barcoding of commercial bêche-de-mer species (Echinodermata: Holothuroidea). Molecular Ecology Resources, 10(4): 634-646. doi: 10.1111/j.17550998.2009.02826.x

You, L., Zhao, M., Regenstein, J. M., \& Ren, J. (2010). Purification and identification of antioxidative peptides from loach (Misgurnus anguillicaudatus) protein hydrolysate by consecutive chromatography and electrospray ionization-mass spectrometry. Food Research International, 43(4), 1167-1173. doi: 10.1016/j.foodres.2010.02.009

Yuniati, R., \& Sulardiono, B. (2019). Exploration of the collagen of non commercial sea cucumber Holothuria atra and commercial sea cucumber Stichopus vastus in the Karimunjawa Islands, Indonesia. Ocean Life, 3(1), 18-23. doi: 10.13057/oceanlife/o030103 